\title{
Examining the Relationship among Brand Commitment, Brand Trust, and Brand Citizenship Behavior in the Service Industry*
}

\author{
Análisis de la relación entre el compromiso de marca, la confianza en la marca \\ y la ciudadanía corporativa de las marcas en la industria de servicios
}

\author{
Nurina Putri Handayani \\ Master in Management, Universitas Multimedia Nusantara, \\ Tangerang-Indonesia, nurina.putri@umn.ac.id \\ Aldrin Herwany \\ Doctoral in Financial Management, Universitas Padjadjaran, \\ Bandung-Indonesia, aldrin.herwany@fe.unpad.ac.id
}

\begin{abstract}
How to cite / Cómo citar
Handayani, N. P., \& Herwany, A. (2020). Examining the Relationship among Brand Commitment, Brand Trust, and Brand Citizenship Behavior in the Service Industry. Revista CEA, 6(11), 13-23. https://doi.org/10.22430/24223182.1459
\end{abstract}

Received: 8 August 2019

Accepted: 30 September 2019

\begin{abstract}
Brands are strategic prerequisites that help organizations to generate more value for customers and sustainable competitive advantage among competitors. Employee behavior is crucial for brand success because the service provided by employees is located in the interface between brand commitment and brand delivery. As a result, an increasing number of banks is encouraging their employees to be more competitive and improve the efficacy and stability of the banking sector. The main objective of this work is to investigate the relationships among brand commitment, brand trust, and brand citizenship behavior in private banks. The data were collected from 249 respondents from private banking companies in Indonesia. Structural equation modelling was used to test research hypotheses, and a highly reliable and valid model was developed. The findings indicate that brand commitment has a positive effect on brand citizenship behavior, while brand trust is not a predictor of brand citizenship behavior. Furthermore, there is a correlation between brand commitment and brand trust. These findings provide useful insight and suggestions for managers in the banking sector.
\end{abstract}

\footnotetext{
${ }^{*}$ This article is derived from the Research Contract Number 31/AKM/MONOPNT/2019 dated March 27th, 2019 and has been funded with Direktorat Riset, Pengabdian Masyarakat, Kementerian Riset, Teknologi, and Pendidikan Tinggi Republik Indonesia resources.
} 
Keywords: Brand commitment, brand trust, brand citizenship behavior.

JEL Classification: J24, G21, M32.

\section{Resumen}

Una marca es un prerrequisito estratégico que ayuda a las organizaciones a generar más valor para sus clientes y una ventaja competitiva sostenible entre sus competidores. El comportamiento de los empleados es crucial para el éxito de la marca porque el servicio que prestan se encuentra en la interfaz entre el compromiso de la marca y el cumplimiento de la misma. Un número creciente de bancos ofrece la oportunidad de alentar a las empresas a ser más competitivas y mejorar la eficacia y la estabilidad de la banca. El objetivo principal de este artículo es estudiar las relaciones entre el compromiso de marca, la confianza en la marca y la ciudadanía corporativa de las marcas en bancos privados. Los datos fueron recolectados de 249 encuestados en compañías de banca privada en Indonesia. Se utilizó el modelado de ecuaciones estructurales para probar la hipótesis de investigación y se desarrolló un modelo con alta confiabilidad y validez. Los resultados indican que el compromiso de la marca tiene un efecto positivo en la ciudadanía corporativa de la marca, mientras que la confianza en la marca no es un predictor de dicha ciudadanía. Además, existe una correlación entre el compromiso de la marca y la confianza en la marca. Estos hallazgos proporcionan ideas y sugerencias útiles para la gestión corporativa en el sector bancario.

Palabras clave: compromiso de marca, confianza en la marca, ciudadanía corporativa.

Clasificación JEL: J24, G21, M32.

\section{INTRODUCTION}

Brands can be built and used by managers, but they are also strategic prerequisites that help organizations to generate more value for customers and sustainable competitive advantage among competitors (Sun \& Ghiselli, 2010). A brand is the most valuable asset of every organization, and it can pave the way to gaining a more significant share of the market and more profits through proper management (Ghenaatgar \& Jalali, 2016). Internal branding also plays a significant role in the weight of a company that introduces its brand to competitors and society, showing company durability in order to increase brand commitment, brand trust, and brand citizenship behavior.

Internal branding activities focusing on increasing employee awareness of, knowledge of, and commitment to their corporate brand are central for the successful implementation of company policies, such as sustainability (Baumgarth \& Schmidt, 2010; Burmann \& Zeplin, 2005; Foster et al., 2010). Besides, prior studies confirm that employee engagement is increased through practical internal branding activities, which helps to improve business performance (Gapp \& Merrilees, 2006). Internal branding has emerged as a means to create a corporate brand by aligning employees' attitudes and behaviors with brand commitment (Erkmen \& Hancer, 2015).

Employees of a service provider could create or crush the company's brand. On the other hand, Schultz and de Chernatony (2002) argue that organizations rely on employees to fulfil their brand 
promise. Moreover, according to Morhart et al., (2009), customer's perception relies on service performance and attitude as demonstrated/performed by front liners.

An increasing number of banks is encouraging their employees to be more competitive and improve the efficacy and stability of the banking sector. Banking industry employees play vital roles, and their actions are evaluated based on certain features and the effectiveness of said actions. Hence, brand citizenship behavior should be considered to be the variable that determines customer experience in the banking industry (Ghenaatgar \& Jalali, 2016). If companies display brand citizenship behaviors successfully (following their psychological contract), employee commitment and trust in the brand and the company increase.

\section{THEORETICAL FRAMEWORK}

Brand trust could be defined as the willingness of a customer to have confidence in the reliability and honesty of a specific brand (Moorman et al., 1993; Morgan \& Hunt, 1994). Organizations can proactively affect the brand trust of consumers (and, likewise, that of potential and current employees). Trust in organizations differs from trust between people, as the former also covers "the organization's institutionalized processes and principles" (Searle et al., 2011). In the customerservice provider relationship, trust has also been reported to aid the development of customer commitment (Bowden, 2014). Furthermore, trust is a fundamental aspect of genuine commitment (Hess \& Story 2005).

Employee behavior is crucial for the brand's success because the service they provide is located in the interface between brand agreement and brand delivery (Foster et al., 2010). In order to understand what is expected from employees to live the brand, Burmann and Zeplin (2005) developed the concept of brand citizenship behavior across the construct of organizational citizenship behavior. Such construct mainly states that employee behavior can enhance the fulfilment of the brand promise by including external behaviors as well as intra-organizational behaviors. According to the commitment-trust theory of relationships (Morgan \& Hunt, 1994), trust is a crucial concept to explain people's desire to stay in a long-term relationship, such as one with a brand (Erkmen \& Hancer, 2015).

Burmann and Zeplin (2005) define brand commitment as the extent of psychological attachment of employees to the brand. Employee brand commitment is related to their sense of belonging (Punjaisri et al., 2017). A person who has a sense of belonging to an organization possesses a specific type of common sense by which they would then define him / herself in relation to that organization (Bhattacharya et al., 1995).

Under the category of employee characteristics, Podsakoff et al., (2000) reported that organizational commitment is what is most commonly identified as an antecedent to organizational citizenship behavior (OCB). In the case of corporate brands, brand commitment is perceived as synonymous with organizational commitment (Burmann et al., 2009). Erkmen and Hancer (2015) stated that commitment is the key to understand how employees adopt brand citizenship behaviors and behave in accordance with the brand promise. Moreover, internal commitment has been proposed as one of the main challenges for the success of branding because commitment leads employees to believe in their service brand (de Chernatony et al., 2003). 
Trust, which has been proposed to be an antecedent of commitment, exists when one party has confidence in the other party's reliability and integrity (Morgan \& Hunt, 1994). Similarly, trust is also essential to improve commitment and enhance relationships within the context of branding (Bowden, 2014). Therefore, it is reasonable to argue that the brand trust of employees might also enhance their commitment to the brand. Erkmen and Hancer (2015) found that brand commitment has a direct and positive effect on employee brand trust. Based on these discussions, the following hypotheses are proposed in this work:

H1: Brand trust has a positive impact on brand citizenship behavior.

$\mathrm{H} 2$ : Brand commitment has a positive impact on brand citizenship behavior.

H3: There is a correlation between brand trust and brand commitment.

\section{METHOD}

\section{Participants}

Generation $Y$ individuals who work in some private banks in Indonesia participated in this research. They are known as millennial workers, people born between 1977 and 2002 (Dessler, 2013). Three hundred questionnaires were distributed offline directly to employee banking in the Greater Jakarta area. A total of 268 questionnaires were responded and sent back, but $7.1 \%$ of them did not meet the criteria or had some unanswered questions. Hence, the total number of respondents in this study was 249. Table 1 shows that the age of most respondents ranges between 23 and 27. Additionally, most of them have been working at the same company for one to three years.

Table 1. Demographic profile of respondents

Tabla 1. Perfil demográfico de los encuestados

\begin{tabular}{llcc}
\hline & & Number & Percentage \\
\hline \multirow{3}{*}{ Gender } & Male & 95 & $38.15 \%$ \\
& Female & 154 & $61.85 \%$ \\
\hline \multirow{3}{*}{ Age } & $19-23$ & 90 & $36.14 \%$ \\
& $23-27$ & 116 & $46.58 \%$ \\
& $28-32$ & 17 & $4.7 \%$ \\
Years at current company & $33-37$ & 26 & $12.58 \%$ \\
\cline { 2 - 3 } & $1-3$ & 130 & $52.2 \%$ \\
& $5-7$ & 86 & $34.53 \%$ \\
& $>7$ & 13 & $5.22 \%$ \\
\hline \multirow{3}{*}{ Educational attainment } & High school diploma & 20 & $8.05 \%$ \\
\cline { 2 - 3 } & Machelor's degree & 21 & $8.43 \%$ \\
& Master's degree & 204 & $81.92 \%$ \\
& Doctoral degree & 24 & $9.63 \%$ \\
\hline
\end{tabular}

Source: Created by authors. 


\section{Measurement}

In this study, brand commitment was measured as described by Chaudhuri and Holbrook (2002). In turn, brand trust was measured using an adaptation of the instruments proposed by Erkmen and Hancer (2015). Brand citizenship behavior was studied with the instrument created by Bettencourt (1997) and Arnett et al., (2003). All constructs were measured on a six-point Likert scale (ranging from strongly disagree to strongly agree) to assess respondents' attitudes and behaviors.

\section{Procedures}

The survey was administered by providing each participant with a package that contained a statement summarizing the objectives of the study written in simple language, a questionnaire, and a souvenir. The packages were delivered by the managers/supervisors of the participants, who are their employees. Inside the package, a reply-paid envelope was also provided so that participants could confidentially return the questionnaire to the researchers. A total of 300 questionnaires were distributed, and the response rate was as high as $89.3 \%$.

\section{RESULTS}

\section{Validity and Reliability Test Results}

According to Hair et al., (2014), an indicator is valid if its factor loading estimates are higher than 0.5. In Table 2, all the indicators have standard factor loadings that exceed 0.5, which means that all of them are valid. Considering the recommended levels, 0.70 for CR and 0.50 for AVE (Hair et al., 2014), all the constructs in brand commitment, brand trust, and brand citizenship behavior meet the criteria of composite reliability and average variance extracted. Table 2 presents the summary statistics of standard factor loading, CR, and AVE values of all the variables and indicators.

\section{Goodness-of-Fit Test Results}

A structural model was then designed using AMOS software. In that stage, several criteria were considered for assessing the structural model and ensuring it fit the data well. As shown in Table 3, the fit criteria of the structural model achieved the recommended values suggested by Hair et al., (2014); the Root Mean Square Error of Approximation (RMSEA) was 0.068. Other fit indices (i.e., absolute fit indices, incremental fit indices, parsimony fit indices) were $\mathrm{df}=730$; normed chi-square = 2.156; Normed Fit Index (NFI) = 0.932; Comparative Fit Index (CFI) = 0.962; and Parsimonious Normed Fit Index $(\mathrm{PNFI})=0.741$. Based on these results, it can be said that the structural model achieved an adequate fit for the data. 
Table 2. Validity and reliability

Tabla 2. Validez y confiabilidad

\begin{tabular}{|c|c|c|c|c|}
\hline $\begin{array}{l}\text { Latent } \\
\text { Variable }\end{array}$ & Items & $\begin{array}{l}\text { Standard } \\
\text { Factor } \\
\text { Loading }\end{array}$ & $\mathrm{CR}$ & AVE \\
\hline \multirow{5}{*}{$\begin{array}{l}\text { Brand } \\
\text { Commitment }\end{array}$} & $\begin{array}{l}\text { BC 1: When I chose this company as my workplace, I } \\
\text { cared a lot about the company's brand. }\end{array}$ & 0.788 & \multirow{5}{*}{0.856} & \multirow{5}{*}{0.545} \\
\hline & $\begin{array}{l}\text { BC } 2 \text { : This is the banking company with the best brand to } \\
\text { work at. }\end{array}$ & 0.76 & & \\
\hline & $\begin{array}{l}\text { BC 3: Most of the time, I tell my colleagues that this } \\
\text { company is a great place to work at. }\end{array}$ & 0.798 & & \\
\hline & $\begin{array}{l}\text { BC 4: I am pleased to work at this company compared to } \\
\text { other banking companies. }\end{array}$ & 0.661 & & \\
\hline & $\begin{array}{l}\text { BC 5: I am going to do a good job to be able to keep } \\
\text { working at this company. }\end{array}$ & 0.671 & & \\
\hline \multirow{4}{*}{ Brand Trust } & BT 1: I trust the company's brand. & 0.788 & \multirow{4}{*}{0.859} & \multirow{4}{*}{0.605} \\
\hline & BT 2: When I work, I depend on the company's brand. & 0.74 & & \\
\hline & BT 3: This is an honest banking company. & 0.762 & & \\
\hline & BT 4: This is a reliable banking company. & 0.818 & & \\
\hline \multirow{5}{*}{$\begin{array}{l}\text { Brand } \\
\text { Citizenship } \\
\text { Behavior }\end{array}$} & $\begin{array}{l}\text { BCB 1: Most of the time, I talk about the good aspects of } \\
\text { the company in my community. }\end{array}$ & 0.686 & \multirow{5}{*}{0.865} & \multirow{5}{*}{0.618} \\
\hline & $\begin{array}{l}\text { BCB 2: I communicate to my manager any idea I have to } \\
\text { consolidate the company's brand image. }\end{array}$ & 0.831 & & \\
\hline & BCB 3: I communicate to my manager any idea I have to & & & \\
\hline & improve the company's brand performance. & 0.862 & & \\
\hline & $\begin{array}{l}\text { BCB 4: Most of the time, I provide feedback so that the } \\
\text { company can improve its consumer brand experience. }\end{array}$ & 0.753 & & \\
\hline
\end{tabular}

Source: Created by authors.

Table 3. Goodness of fit

Tabla 3. Bondad de ajuste

\begin{tabular}{|c|c|c|c|}
\hline $\begin{array}{l}\text { Goodness-of-Fit (GOF) } \\
\text { units }\end{array}$ & Acceptable degree of compatibility & Estimated result & Test criteria \\
\hline X2 Value & - & 133.654 & - \\
\hline DF & - & 62 & - \\
\hline \multicolumn{4}{|l|}{ Absolute Fit indices } \\
\hline Chi-Square & $\begin{array}{l}\left(\chi^{2} / D F\right)<3 \text { is very good } \\
\text { or } 2 \leq\left(\chi^{2} / D F\right) \leq 5 \text { is acceptable }\end{array}$ & 2.156 & \multirow{2}{*}{$\begin{array}{l}\text { Acceptable fit } \\
\text { Acceptable fit }\end{array}$} \\
\hline RMSEA & RMSEA $<0.08$ & 0.068 & \\
\hline \multicolumn{4}{|l|}{ Incremental Fit indices } \\
\hline NFI & $\begin{array}{l}0 \leq \mathrm{NFI} \leq 1 \text {, model with perfect fit } \\
\text { would produce an NFI of } 1\end{array}$ & 0.932 & Acceptable fit \\
\hline $\mathrm{CFI}$ & $\mathrm{CFI} \geq 0.95$ & 0.962 & Acceptable fit \\
\hline \multicolumn{4}{|l|}{ Parsimony Fit indices } \\
\hline PNFI & $\begin{array}{l}0 \leq N F I \leq 1 \text {, relatively high values } \\
\text { represent relatively better fit }\end{array}$ & 0.741 & Acceptable fit \\
\hline
\end{tabular}




\section{Hypothesis Testing}

Structural equation modeling (SEM) was used to test the model and the hypotheses. The hypotheses were analyzed using AMOS 22.0 software. The hypothesis test was conducted after the validity of the structural model was proven in order to test the structural theory in this study. To test the hypothesis regression, some output from the structural model was used.

As shown in Table 4, the findings indicate that brand trust is not a predictor of brand citizenship behavior ( $\beta=-0.019$, $t$-value $=-0.104, p>0.05)$; hence, $\mathrm{H} 1$ is not accepted. In turn, the effect of brand commitment on brand citizenship behavior is positive and statistically significant ( $\beta=0.773$, $t$-value $=4.128, \mathrm{p}<0.05)$; consequently, $\mathrm{H} 2$ is supported. The results in the table above show that $\mathrm{H} 3$ is also supported because there is a correlation between brand trust and brand commitment $(\beta=0.384$, tvalue $=8.227, p>0.05$ )

Table 4. Findings

Tabla 4. Resultados de la investigación

\begin{tabular}{|c|c|c|c|c|c|c|}
\hline & Hypothesized effect & $\begin{array}{l}\text { Std. } \\
\text { Estimate }\end{array}$ & S. E. & C. R. & $P$ & Decision \\
\hline $\mathrm{H} 1$ : & $\begin{array}{l}\text { Brand trust has a positive impact on brand } \\
\text { citizenship behavior. }\end{array}$ & -0.019 & 0.185 & -0.104 & 0.917 & Not Supported \\
\hline $\mathrm{H} 2$ : & $\begin{array}{l}\text { Brand commitment has a positive impact on } \\
\text { brand citizenship behavior. }\end{array}$ & 0.773 & 0.187 & 4.128 & $* * *$ & Supported \\
\hline H3: & $\begin{array}{l}\text { There is a correlation between brand trust and } \\
\text { brand commitment. }\end{array}$ & 0.384 & 0.047 & 8.227 & $* * *$ & Supported \\
\hline
\end{tabular}

Source: Created by authors.

\section{DISCUSSION}

This study shows that brand trust does not positively affect brand citizenship behavior. Such result contradicts the work by Erkmen and Hancer (2015), in which brand trust has a positive impact on said behavior. Ghenaatgar and Jalali (2016) hold that internal branding, job satisfaction, and brand commitment are predictors of brand trust. According to Özçelik and Fındıklı (2014), internal branding is associated with organizational citizenship behavior, which is similar to brand citizenship behavior.

A previous study by Piehler et al., (2016) is in line with the result in this work, where brand commitment is a predictor of brand citizenship behavior. Such study identified brand understanding and brand commitment as two scopes of brand citizenship behaviors. When employees understand the company's brand, they will try to know more and commit to the company's brand; this will encourage increased brand citizenship behavior. There are many benefits of high employee commitment to a company's brand. One of them is that they will recommend the company as an excellent place to work to their relatives by word of mouth, which is a very low-cost promotion tool, yet very useful to attract new employees.

The findings above show that there is a correlation between brand trust and brand commitment. This result supports those obtained by Moreira and Silva (2015), which suggest that trust and commitment are essential for ensuring long-lasting relationships and diminishing the risk of anticipated 
opportunistic behavior (Erdem \& Swait, 2004). Moreover, this result is in line with a previous work by App and Büttgen (2016). Therefore, trust in the company's brand determines the continuity of work relationships among workers and contributes to their commitment to the company's brand, which, in turn, supports longs-lasting relationships (Chaudhuri \& Holbrook, 2002; Delgado-Ballester \& Munuera-Alemán, 2001; Morgan \& Hunt, 1994).

\section{CONCLUSIONS}

A corporate leader should appropriately understand the culture, values, and norms a company has embraced. An honest, open-minded leader can inspire employees to develop brand trust. In an environment of trust and openness, employees can offer and take advice and opinions, and they can also use their aspirations to contribute to the company. When employees trust a company, the latter is expected to help them improve their work performance, which has a positive impact on the company's brand image.

A transparent reward system is one of the demands of millennial workers. Rewards can be either financial or non-financial: bonuses, incentives, promotions, plane tickets, or even additional days off. Differentiated rewards are one of the reasons why millennial workers decide to move to another company. Therefore, equitable and transparent rewards could be a practical corporate approach to improve employee commitment.

The existence of a positive relationship between trust and commitment is essential. Moreover, in order to retain knowledgeable workers, organizations must focus on strengthening their employees' commitment by offering rewards, recognition, better compensation, and also a better work environment. The participants in this study are employees of banking companies, and a few of them only meet each other online; therefore, their companies should provide opportunities to gather and interact face to face, not only for work-related purposes. This can promote organizational citizenship behavior among employees.

The limitation of this research is that one of the three hypotheses is not supported. Furthermore, the results show significant differences compared to a previous study by the author, where similar concepts were examined with different participants, i.e., generation $Y$ individuals in state banking companies. It could be implied, from this study, that brand commitment positively influences brand citizenship behavior; nevertheless, further research could examine the connection between those two variables in other service industries, such as hospitality, education, or health care. This work is an attempt to find out more about the relationship between such variables.

\section{ACKNOWLEDGMENT}

The authors would like to thank Direktorat Riset, Pengabdian Masyarakat, Kementerian Riset, Teknologi, and Pendidikan Tinggi Republik Indonesia for providing financial support for this study under Research Contract Number 31/AKM/MONOPNT/2019 dated March 27th, 2019. 


\section{REFERENCES}

App, S., \& Büttgen, M. (2016). Lasting footprints of the employer brand: Can sustainable HRM lead to brand commitment? Employee Relations, 38(5), 703-723. https://doi.org/10.1108/er-06-2015$\underline{0122}$

Arnett, D. B., German, S. D., \& Hunt, S. D. (2003). The Identity Salience Model of Relationship Marketing Success: The Case of Nonprofit Marketing. Journal of Marketing, 67(2), 89-105. https://doi.org/10.1509/jmkg.67.2.89.18614

Baumgarth, C., \& Schmidt, M. (2010). How strong is the business-to-business brand in the workforce? An empirically-tested model of 'internal brand equity' in a business-to-business setting. Industrial Marketing Management, 39(8), 1250-1260. https://doi.org/10.1016/i.indmarman.2010.02.022

Bettencourt, L. A. (1997). Customer voluntary performance: Customers as partners in service delivery. Journal of Retailing, 73(3), 383-406. https://doi.org/10.1016/s0022-4359(97)90024-5

Bhattacharya, C. B., Rao, H., \& Glynn, M. A. (1995). Understanding the Bond of Identification: An Investigation of Its Correlates among Art Museum Members. Journal of Marketing, 59(4), 46-57. https://doi.org/10.2307/1252327

Bowden, J. L. H. (2014). The Process of Customer Engagement: A Conceptual Framework. Journal of Marketing Theory and Practice, 17(1), 63-74. https://doi.org/10.2753/mtp1069-6679170105

Burmann, C., \& Zeplin, S. (2005). Building brand commitment: A behavioural approach to internal brand management. Journal of Brand Management, 12(4), 279-300. https://doi.org/10.1057/palgrave.bm.2540223

Burmann, C., Zeplin, S., \& Riley, N. (2009). Key determinants of internal brand management success: An exploratory empirical analysis. Journal of Brand Management, 16(4), 264-284. https://doi.org/10.1057/bm.2008.6

Chaudhuri, A., \& Holbrook, M. B. (2002). Product-class effects on brand commitment and brand outcomes: The role of brand trust and brand affect. Journal of Brand Management, 10(1), 33-58. https://doi.org/10.1057/palgrave.bm.2540100

Delgado-Ballester, E., \& Munuera-Alemán, J. L. (2001). Brand trust in the context of consumer loyalty. European Journal of Marketing, 35(11/12), 1238-1258. https://doi.org/10.1108/eum0000000006475

de Chernatony, L., Drury, S., \& Segal-Horn, S. (2003). Building a Services Brand: Stages, People and Orientations. The Service Industries Journal, 23(3), 1-21. https://doi.org/10.1080/714005116

Dessler, G. (2013). Human Resource Management (13th ed.). Pearson Education. 
Erdem, T., \& Swait, J. (2004). Brand Credibility, Brand Consideration, and Choice. Journal of Consumer Research, 31(1), 191-198. https://doi.org/10.1086/383434

Erkmen, E., \& Hancer, M. (2015). Linking brand commitment and brand citizenship behaviors of airline employees: "The role of trust". Journal of Air Transport Management, 42, 47-54. https://doi.org/10.1016/i.jairtraman.2014.08.001

Foster, C., Punjaisri, K., \& Cheng, R. (2010). Exploring the relationship between corporate, internal and employer branding. Journal of Product \& Brand Management, 19(6), 401-409. https://doi.org/10.1108/10610421011085712

Gapp, R., \& Merrilees, B. (2006). Important factors to consider when using internal branding as a management strategy: A healthcare case study. Journal of Brand Management, 14(1-2), 162-176. https://doi.org/10.1057/palgrave.bm.2550058

Ghenaatgar. A., \& Jalali S. M., (2016). Study of the effect internal brand management on brand citizenship behavior in presence of brand commitment and job satisfaction of employees in banking industry. International Business Management, 10(18). 4200-4208. URL

Hair, J. F., Black, W. C., Babin, B. J., \& Anderson, R. E. (2014). Multivariate data analysis a global perspective. Pearson.

Hess, J., \& Story, J. (2005). Trust-based commitment: multidimensional consumer-brand relationships. Journal of Consumer Marketing, 22(6), 313-322. https://doi.org/10.1108/07363760510623902

Moorman, C., Deshpande, R., \& Zaltman, G. (1993). Factors Affecting Trust in Market Research Relationships. Journal of Marketing, 57(1), 81-101. https://doi.org/10.2307/1252059

Moreira, A. C., \& Silva, P. M. (2015). The trust-commitment challenge in service quality-loyalty relationships. International Journal of Health Care Quality Assurance, 28(3), 253-266. https://doi.org/10.1108/ijhcqa-02-2014-0017

Morgan, R. M., \& Hunt, S.D. (1994). The Commitment-Trust Theory of Relationship Marketing. Journal of Marketing, 58(3), 20-38. https://doi.org/10.2307/1252308

Morhart, F. M., Herzog, W., \& Tomczak, T. (2009). Brand-Specific Leadership: Turning Employees into Brand Champions. Journal of Marketing, 73(5), 122-142. https://doi.org/10.1509/jmkg.73.5.122

Özçelik, G., \& Fındıklı, M. A. (September 2014). The Relationship between Internal Branding and Organizational Citizenship Behaviour: The Mediating Role of Person-Organization Fit. Procedia Social and Behavioral Sciences, 150, 2014, pp. 1120-1128. https://doi.org/10.1016/j.sbspro.2014.09.127

Piehler, R., King, C., Burmann, C., \& Xiong, L. (2016). The importance of employee brand understanding, brand identification, and brand commitment in realizing brand citizenship 
behaviour. European Journal of Marketing, 50(9/10), 1575-1601. https://doi.org/10.1108/ejm$\underline{11-2014-0725}$

Podsakoff, P., Mackenzie, S. B., Paine, J. B., \& Bachrach, D. G. (2000). Organizational citizenship behaviors: A critical review of the theoretical and empirical literature and suggestions for future research. Journal of Management, 26(3), 513-563. https://doi.org/10.1016/s01492063(00)00047-7

Punjaisri, K., \& Wilson, A. (2017). The Role of Internal Branding in the Delivery of Employee Brand Promise. In Advances in Corporate Branding. Journal of Brand Management: Advanced Collections. https://doi.org/10.1057/978-1-352-00008-5 6

Schultz, M., \& de Chernatony, L. (2002). Introduction: The Challenges of Corporate Branding. Corporate Reputation Review, 5(2-3), 105-112. https://doi.org/10.1057/palgrave.crr.1540168

Searle, R., Den Hartog, D. N., Weibel, A., Gillespie, N., Six, F., Hatzakis, T., \& Skinner, D. (2011). Trust in the employer: the role of high-involvement work practices and procedural justice in European organizations. The International Journal of Human Resource Management, 22(5), 1069-1092. https://doi.org/10.1080/09585192.2011.556782

Sun, L., \& Ghiselli, R. F. (2010). Developing a Conceptual Model of Brand Equity in the Hotel Industry Based on Aaker's Perspective. Journal of Quality Assurance in Hospitality \& Tourism, 11(3), 147161. https://doi.org/10.1080/1528008x.2010.483417 